\title{
Analysis of Humidity, Temperature, Working Period, and Personal Protective Equipment in Home Industry at Gold Craftsmen
}

\author{
Nur Juliana $^{1 *}$, Anwar Mallongi ${ }^{2}$, Wa Ode Megasari ${ }^{3}$ \\ ${ }^{1}$ Department of Health Promotion, Politeknik Karya Persada Muna, Indonesia \\ ${ }^{2}$ Department of Environmental Health, Hasanuddin University, Indonesia \\ ${ }^{3}$ Department of Hospital Administration, Politeknik Karya Persada Muna, Indonesia \\ *Coresponding author: juli.faidah@gmail.com
}

\begin{abstract}
Home industries, especially gold craftsmen in Malimongan Village, Makassar City, working indoors can experience pressure on hot and cold. In addition, the working period has been decades and used personal protective equipment used as protection from the exposure of toxic in the work of environment. The purpose is to determine humidity temperature, working period, and the use of personal protective equipment in the home industry at gold craftsmen. This study is descriptive observational. The direct collection was used a thermohygrometer, samples of 30 houses, interviews through questionnaires amounted to 30 human samples were chosen using the simple random sampling. The analyzed using the frequency distribution of each variable. The results showed that the humidity of the room $66,7 \%$ did not meet the requirements and 33,3\% met the requirements. The air temperature was $86,7 \%$ did not meet the requirements and $13,3 \%$ met the requirements. The working period of gold craftsmen $>5$ years is $96,7 \%$ and the tenure of $<5$ years is 3,3\%, the average working period is 15,57 years. Respondents never used personal protective equipment $93,3 \%$ and $6,7 \%$ sometimes used a towel to cover the nose. The average air humidity does not meet the requirements, the average temperature does not meet the requirements, the average service life is more than 5 years, and on average never used personal protective equipment. It is expected in the home industry needs to increase ventilation in the workspace so that air of circulation can enter properly, gold craftsmen need to use personal protective equipment while working.
\end{abstract}

Keywords: Humidity, temperature, working period, personal protective equipment

\section{Introduction}

The physical work environment in the workplace both are open and closed, greatly affects various types of production, one of the factors that affect the work environment was the work climate (Kuswana, 2014). Work climate is one of the physical factors that have the potential to cause problems of health for workers when in extreme conditions. Extreme working of environment temperature conditions includes heat and cold that are beyond the limits of human ability for adaptation (Suma'mur, 2009).

The problems that exist in the home industry, especially gold craftsmen in the Malimongan Village, Makassar City, work indoors can experience pressure are hot and cold. Heat stress is a limitation of the body receiving heat loads when doing work and environmental factors such as exposure to hot environmental temperatures, humidity physical loads such as insufficient rest time, and use by clothing (Wulandari, 2016).

Research proves that good air quality conditions in the room have a humidity percentage of around $40-60 \%$. If the percentage of humidity is higher than the standard, it will trigger the 
growth of fungi that are allergens (Citraswari, 2015). Then, temperatures that are too high or low in the room cause uncomfortable conditions and can affect health. The high and low indoor temperature can depend on the intensity of the sun, during the day of the indoor temperature can be higher than the temperature in the morning or evening. The Humidity in a room is influenced by the temperature in the room (Sari DW et al, 2021). The temperature and humidity in the room given greatly activities of affect such as the workspace at gold craftsmen.

The working period has a tendency factor of the risk for obstruction of workers in dusty places for more than 5 years (Febrianto, 2015). Workers who have a longer working period have the advantage of detecting, understanding, and finding the causes of errors at work, to minimize errors in the production process (Suma'mur, 2009). However, the longer the working period, the more risky the worker is exposed to diseases that exist in the workplace. The results of previous studies also show that work experience has a positive and significant effect on work productivity (Ukkas, 2017). Furthermore, Personal protective equipment is very important to be used by workers in carrying out work whose function is to isolate the body from potential hazards in the workplace (Tarkawa, 2008).

Gold craftsmen are people who worked was make jewelry from gold. A starting from gold raw materials through a manufacturing process that is processed into various types of jewelry such as necklaces, earrings, rings, bracelets, earrings, and so on. The manufacture of gold jewelry consists of selecting raw materials, smelting, refining using chemicals made from nitrate, mercury, and other chemicals, then welding, coating materials, and polishing metals into gold.

Based on the initial survey, the workspace of gold craftsmen is carried out in the house, even together with the family. The work period has been for many years and even decades have worked as a gold craftsman. This has been done continuously, when there are orders from customers, the craftsmen are enthusiastic about making gold crafts because it is to support their economic needs. In addition, the use of personal protective equipment is rarely used by gold craftsmen as protection from toxic exposure in the work environment. Based on the description above, the researchers are interested in research to determine the humidity, temperature, working period, and the use of personal protective equipment in the home industry of gold craftsmen in Malimongan Village, Makassar City.

\section{Materials and Methods}

This research is descriptive observational. The research location is the home industry of gold craftsmen, Malimongan Village, Wajo District, Makassar City. The search was carried out from April to May 2016. The object population is the house of gold craftsmen, namely 44 houses, the subject population is respondents who work as gold craftsmen. While the sample measurement amounted to 30 houses.

The tool used by the thermohygrometer to measure temperature and humidity in the house is done by a direct reading method. Interviews through questionnaires conducted by gold craftsmen using the Lemeshow formula were 30 people. The sample in this study was taken 
using a simple random sampling technique. This sampling method was carried out randomly without regard to the existing strata in the population (Sugiyono, 2011). Data processing was carried out using the SPSS version 21 computer program, in the form of an analysis of the frequency distribution of each variable. The presentation of data is displayed in the form of tables and narratives.

\section{Results and Discussion}

The measurement indoor of air humidity from 30 houses 10 houses meet the requirements, namely $40 \%-60 \%$ and there are 20 houses with humidity that not eligible of requirements (Table 1).

Table 1. Results of humidity measurements gold craftsman house

\begin{tabular}{|c|c|c|c|}
\hline Locations & Humidity (\%) & Locations & Humidity (\%) \\
\hline House 1 & 66 & House 16 & 66 \\
\hline House 2 & 65 & House 17 & 61 \\
\hline House 3 & 63 & House 18 & 56 \\
\hline House 4 & 59 & House 19 & 58 \\
\hline House 5 & 58 & House 20 & 58 \\
\hline House 6 & 69 & House 21 & 62 \\
\hline House 7 & 64 & House 22 & 61 \\
\hline House 8 & 64 & House 23 & 65 \\
\hline House 9 & 69 & House 24 & 68 \\
\hline House 10 & 68 & House 25 & 67 \\
\hline House 11 & 58 & House 26 & 65 \\
\hline House 12 & 56 & House 27 & 58 \\
\hline House 13 & 62 & House 28 & 59 \\
\hline House 14 & 69 & House 29 & 67 \\
\hline House 15 & 69 & House 30 & 57 \\
\hline
\end{tabular}

Humidity: Qualified (40\%-60\%), not eligible (<40\% and >60\%)

Measurement of air temperature from 30 houses at the gold craftsmen, there were 4 houses with air temperatures qualified of requirements, namely $\left(18-30^{\circ} \mathrm{C}\right)$ and there are 26 houses with temperatures that are not eligible of requirements (Table 2). 
Table 2. Results of temperature measurements gold craftsman house

\begin{tabular}{cccc}
\hline Locations & Temperature $(\boldsymbol{\%})$ & Locations & Temperature $(\boldsymbol{\%})$ \\
\hline House 1 & 30 & House 16 & 32 \\
House 2 & 31 & House 17 & 33 \\
House 3 & 33 & House 18 & 34 \\
House 4 & 34 & House 19 & 35 \\
House 5 & 35 & House 20 & 34 \\
House 6 & 32 & House 21 & 31 \\
House 7 & 31 & House 22 & 33 \\
House 8 & 32 & House 23 & 31 \\
House 9 & 30 & House 24 & 30 \\
House 10 & 32 & House 25 & 32 \\
House 11 & 34 & House 26 & 33 \\
House 12 & 35 & House 27 & 34 \\
House 13 & 33 & House 28 & 34 \\
House 14 & 31 & House 29 & 31 \\
House 15 & 30 & House 30 & 33 \\
\hline
\end{tabular}

Temperature : Qualified $\left(18-30^{\circ} \mathrm{C}\right)$, not eligible $\left(<18 \% 0 \mathrm{C}\right.$ dan $\left.>30^{\circ} \mathrm{C}\right)$

Humidity was not eligible requirements with a percentage of $66,7 \%$ and qualified requirements with a percentage of $33,3 \%$. The temperature was not eligible requirements with a percentage of $86,7 \%$, and the temperature qualified requirements with a percentage of $13,3 \%$ (table 2). A variable working period at gold craftsmen $>5$ years was 29 people with a percentage $(96,7 \%)$ and $<5$ years there was 1 person with a percentage of 3,30\%. Variable personal protective equipment at the gold craftsmen sometimes used was 2 people with a percentage of $6,70 \%$ and never used was 28 people with a percentage of $93,3 \%$ with an average of 2,93 and a standard deviation of 0,254 (Table 3).

Table 3. Distribution of humidity, temperature, working period and used personal protective equipment at gold craftsmen

\begin{tabular}{lcc}
\hline \multicolumn{1}{c}{ Variable } & n & $(\%)$ \\
\hline Humidity & & \\
Not eligible $(<40 \%$ dan $>60 \%)$ & 20 & 66,7 \\
Qualified $(40-60 \%)$ & 10 & 33,3 \\
\hline Temperature & 4 & \\
Not eligible $\left(<18 \%{ }^{\circ} \mathrm{C}\right.$ dan $\left.>30^{\circ} \mathrm{C}\right)$ & 26 & 86,7 \\
Qualified $\left(18-30^{\circ} \mathrm{C}\right)$ & & 13,3 \\
\hline Working period & 29 & 96,7 \\
$\geq 5$ year & 1 & 3,30 \\
\hline 5 year & & \\
\hline
\end{tabular}




\section{Personal protective equipment}

Yes

$0 \quad 0$

$\begin{array}{lll}\text { Sometimes } & 2 & 6,70\end{array}$

Never

28

93,3

An average value indoor of air humidity is $62,90 \%$, the humidity minimum-maximum was $56 \%-69 \%$, Std. Deviation 4,389. The average value of indoor air temperature is $32,430 \mathrm{C}$, Std. The temperature of minimum-maximum was $30^{\circ} \mathrm{C}-35^{\circ} \mathrm{C}$, and the standard deviation was 1,591 . The average value of the working period at gold craftsmen is 15,73, Std. Deviation 6,422. The average use of personal protective equipment by gold craftsmen was 2,93 , a standard deviation of 0,254 (Table 4).

Table 4. Analysis of results humidity, temperature, working period, personal protective equipment at gold craftsmen

\begin{tabular}{|c|c|c|c|}
\hline Variable & Mean & Min-Max & SD \\
\hline Humdity & 62,90 & $56-69$ & 4,389 \\
\hline Temperature & 32,43 & $30-35$ & 1,591 \\
\hline Working period & 15,73 & $3 \pm 32$ & 6,422 \\
\hline Personal protective equipment & 2,93 & $2 \pm 3$ & 0,254 \\
\hline
\end{tabular}

The concentration of indoor air pollutants is influenced by several factors, one of which is meteorological factors including humidity and temperature. The relative humidity of the air is the ratio of the amount of water vapor in the air to the maximum amount of water contained in the air at the same temperature and is expressed in percent $(\%)$. Relatively low air humidity $(<40 \%)$ can result in dryness of the mucous membranes. High humidity (>70\%) increases microorganisms (CR Candrasari and J Mukono, 2013).

Refers to the humidity in the house required in (Permenkes RI No. 1077, 2011) which is $40-60 \%$ Rh. The results showed that the highest humidity measurement in the workroom was $69 \%$ in house 6 , house 9 , and house 15 . Houses with the lowest humidity were $56 \%$ in house 12 and house 18. If the indoor humidity does not meet the requirements, it will be a good medium for microorganisms to breed so that they can enter the human body through the skin pores. High humidity is affected by the weather when at the time of measurement, the measurement time is carried out in hot weather conditions, thus affecting the average indoor humidity results. The impact of high humidity in the room causes gold craftsmen to tire easily.

Air temperature plays a very important role in working comfort because the human body produces heat which is used for basal and muscular metabolism. However, of all the energy produced by the body, only $20 \%$ is used and the rest will be discharged into the environment, where the average room temperature is $28,67^{\circ} \mathrm{C}$ (CR Candrasari and J Mukono, 2013). 
Refers to the air temperature in the house required in (Permenkes RI No. 1077, 2011) which is $18-30^{\circ} \mathrm{C}$. Based on the results of the research, the measurement of air temperature in the gold craftsman house was the highest at $35^{\circ} \mathrm{C}$, in house 5 , house 12 and, house 19 . The lowest temperature was $30^{\circ} \mathrm{C}$ in the 1 st house, house 9 , house 15 and, house 24 . The air temperature does not meet the requirements or is not $\operatorname{good}\left(<18^{\circ} \mathrm{C}\right.$ and $\left.>30^{\circ} \mathrm{C}\right)$ with a percentage of $86,7 \%$ while the indoor air temperature meets the requirements or is good with a percentage of $13,3 \%$. The high room temperature is caused by the narrow room and blends with the dwelling. In addition, the workspace is still semi-permanent and there is a lack of ventilation in the room, causing the room temperature to become hot and increase in temperature. The impact of high indoor temperatures causes body heat so it is easy to sweat and interfere with work comfort.

The results to Sarinda A (2017), the average temperature measurement shows that the highest average is in room $35 \mathrm{C} 201\left(28,445^{\circ} \mathrm{C}\right)$, while the lowest is in room $35 \mathrm{E} 105\left(27,8^{\circ} \mathrm{C}\right)$. The average temperature of the four rooms is above the optimal comfort scale of $28,1^{\circ} \mathrm{C}$, or higher. The lowest average temperature was obtained at $06.00 \mathrm{WIB}$ with a temperature of $26^{\circ} \mathrm{C}$ and the highest average temperature was at 13.00 which reached $29,525^{\circ} \mathrm{C}$. The results of $\mathrm{S}$ Mulyati (2020) in the printing room, frying room in the production room by measuring the temperature during the day, namely $30.7^{0} \mathrm{C}, 31,50 \mathrm{C}, 27,3^{\circ} \mathrm{C}$. The three rooms that do not meet the requirements are the printing room and the frying room. While the humidity of the room during the day from the 3 rooms became the measurement point, namely the three rooms did not meet the requirements $(100 \%)$.

Working in a work environment with hot temperatures causes a decrease in body fluids so that it can lead to dehydration of craftsmen. According to Mapoma et al (2014), the concentration of air pollutants is strongly influenced by factors of temperature, humidity, wind speed. Air temperature has an effect because of the chemical reaction of some pollutants that will take place quickly at high temperatures. Humidity is closely related to the deposition of various types of pollutants. Air pollutants will move from areas of low pressure and the transfer process is highly dependent on the direction of wind speed.

Based on the results of the research that the working period of gold craftsmen who worked $>5$ years with a percentage of $96,7 \%$ and worked $<5$ years with a percentage of 3,30\%. The period of service is the length of time the respondent works as a gold craftsman calculated from the time he first worked in a matter of years. The working period of gold craftsmen is between 3 32 years and the average is 15,57 years. The longer the gold craftsman works in a closed space, the easier it is to be exposed to the work environment such as humidity and air temperature.

The working period shows the length of exposure at work. The longer you work in a place, the greater the possibility of being exposed to the work environment (Apriyani, 2014). Research (Puspariani DA et al, 2016) working period of $<5$ years $66,7 \%$ and $>5$ years 33,3\% with an average working period of 7.636 years. Research by Dinda L and Lailatul M, (2018) the tenure of most of the respondents is between 6 to 10 years of work 48,78\%, while respondents with a working period of 1 to 5 years of work are 46,34\%. This shows that the majority of Home 
Industry X workers are employees who have worked for a long time. Research by Puspariani DA et al (2016) the use of personal protective equipment does not meet the requirements of $81,2 \%$ and fulfills the requirements of $18,8 \%$. (Maharani DP and Wahyuningsih AS, 2017) compliance with using personal protective equipment is $80.8 \%$ and not using 19,2\%. Research A Muhith et al (2018) that the behavior of respondents in using masks at work is the most dominant, which is shown in negative behavior with $51,1 \%$. While the positive behavior is $48,9 \%$.

The use of personal protective equipment in the workplace is one of the most important things because the use of personal protective equipment serves to protect workers from exposure to chemicals in the room. On average, respondents did not use personal protective equipment in the form of masks, with $93,3 \%$ and $6,70 \%$ sometimes using a towel to cover their nose. The reason for not using personal protective equipment is because they feel uncomfortable and the habit factor of gold craftsmen. Research by Ratih A et al, (2018) the level of behavior of workers using masks is $72,5 \%$, it can be concluded that the level of behavior of workers in using masks is good. The better the behavior of workers in using masks, the smaller the occurrence of respiratory complaints. The easiest prevention is to use a mask as a protector to reduce the risk of exposure to chemicals and avoid health problems.

\section{Conclusion}

The average air humidity does not meet the requirements, the average temperature does not meet the requirements, the average service life is more than 5 years, and on average they have never used personal protective equipment.

\section{Acknowledgements}

The author would like to thank all gold craftsmen and those who have helped provide opportunities to conduct research, friends, and various parties who have helped provide prayers, support, and motivation in the preparation of this research. The author would also like to thank the supervisors and reviewers for their criticisms and suggestions.

\section{References}

A. Muhith, M. Hannan, Nurul. M, Aknata C.A. (2018). Penggunaan Alat Pelindung Diri (APD) Masker dengan Gangguan Saluran Pernapasan pada Pekerja di PT Bokormas Kota Mojokerto. Jurnal Ilmu Kesehatan, Vol 3(2), page 21-33. https://doi.org/10.24929/jik.v3i1.628

Apriyani, A. (2014). The Influence of Work Climate on Employees Against Dehydration Unit Workshop PT. Indo Acidatama Tbk, Kemiri, Kebakkramat, Karanganyar. Skripsi. Faculty of Public Health. Muhammadiyah University of Surakarta. https://core.ac.uk/download/pdf/148604877.pdf

Citraswari, Husein, A., \& Muryoto. (2015). Hubungan Perilaku Penyehatan Udara di dalam Ruang Rumah dan Gangguan Kesehatan Keluarga di Kelurahan Caturtunggal Wilayah Kerja Puskesmas Depok III, Sleman, Yogyakarya. Jurnal Kesehatan Lingkungan, Vol 6(4), page 157-164. 
https://e-journal.poltekkesjogja.ac.id/index.php/Sanitasi/article/view/839

C.R Candrasari \& J. Mukono. (2013). Hubungan Kualitas Udara Dalam Ruang Dengan Keluhan Penghuni Lembaga Pemasyarakatan Kelas Iia Kabupaten Sidoarjo. Jurnal Kesehatan Lingkungan, Vol 7(1). page 21-25. http://journal.unair.ac.id/filerPDF/keslingdfce63f81bfull.pdf

Dinda. L \& Lailatul. M. (2018). Relationship of Motivation and Work Period with Workers Productivity at Home Industry. The Indonesian Journal of Occupational Safety and Health, Vol 7(2), page 241-248. http://dx.doi.org/10.20473/ijosh.v7i2.2018.240$248 \% 0 \mathrm{~A} \% 0 \mathrm{~A}$

Febrianto, A. (2015). Hubungan Antara Paparan Debu Asap Las (Welding Fume) dan Gas Karbon Monoksida (CO) dengan Gangguan Faal Paru pada Pekerja Bengkel Las (Studi di Kelurahan Ngegel Kecamatan Wonokromo Kota Surabaya). Tesis. Fakultas Kesehatan Masyarakat. Universitas Jember.http://repository.unej.ac.id/handle/123456789/72734

Kuswana, W. (2014). Ergonomi dan Kesehatan dan Keselamatan Kerja. PT. Remaja Rosda Karya. Bandung. https://pustaka.pu.go.id > biblio > ergonomi-dan-k3-kes.

Maharani DP and Wahyuningsih AS. (2017). Pengetahuan, Sikap dan Kebijakan K3 dengan Penggunaan Alat Pelindung Diri di Bagian Ring Spinning Unit 1. Journal of Health Education, Vol 2(1), page 33-38. https://doi.org/10.15294/jhe.v2i1.18823

Mapoma T, Tethani C, Tsakama M, Ishmael BM. (2014). Air Quality Assessment of Carbon monoxide, Nitrogen dioxide and Sulfur dioxide Levels in Blantyre, Malawi: A Statistical Approach to A Stationary Environmental Monitoring Station. African Journal of Environmental Science and Technology., Vol 8(6), page 330-343. https://doi.org/http://doi.org./10.5897/AJEST2014.1696

Mulyati, S. (2020). Analysis of Lighting, Temperature and Humidity Level In The Household Industry Baruna Crackers in Kebun Tebeng of Bengkulu City. Journal of Nursing and Public Health, Vol 8(1), page 104-110. https://jurnal.unived.ac.id

Permenkes RI No. 1077. (2011). PER/MEN/X/2011 tentang faktor fisika dan faktor kimia di tempat kerja. Jakarta http://hukor.kemkes.go.id/uploads/produk_hukum/PMK\%20No.\%201077\%20ttg\%20Ped oman\%20Penyehatan\%20Udara\%20Dalam\%20Ruang\%20Rumah.pdf

Puspariani, Setiani O, Darundiati HY. (2016). Hubungan Masa Kerja dan Lama Kerja Dengan Kadar Timbal $(\mathrm{Pb})$ Dalam Darah Pada Bagian Pengecatan, Industri Karoseri Semarang. Kesehatan Masyarakat, $\quad$ Vol 4(3), 758-766. https://ejournal3.undip.ac.id/index.php/jkm/article/view/13533/13088

Ratih A, Dian A, Elnanda B. (2018). Analysis of Dust Level and Mask Usage Behavior on Rerpiratory Disorder Complaints of Rice Milling Workers. Journal of Vacational Health Studies, Vol 2(1) pages https://doi.org/http://dx.doi.org/10.20473/jvhs.V2.I1.2018.45-50

Sari DW, Rahadiyanti M, Atmaka DR. (2021). Temperature and Humidity Evaluation in Processing Room and Distribution Room at the Nutrition Installation of Sidoarjo Regency Hospital. IAGIKMI \& Universitas Airlangga, Vol 5(1), page 68-74. http://dx.doi.org/10.20473/amnt.v5i1.2021.68-74

Sarinda, Saudarti, Subiki. (2017). Analisis Perubahan Suhu Ruangan Terhadap Kenyamanan Termal Di Gedung 3 FKIP. Jurnal Pembelajaran Fisika, vol 6(3), page 305-311. https://doi.org/10.19184/jpf.v6i3.5329 
Sugiyono. (2011). Metode Penelitian Kuantitatif, Kualitatif dan R \& D (cetakan ke- 14). Alfabeta. Bandung.

Suma'mur. (2009). Hygiene Perusahaan dan Kesehatan Kerja. CV Haji Masagung. Jakarta.

Tarkawa. (2008). Keselamatan dan Kesehatan Kerja. Harapan Press. Surakarta.

Ukkas, I. (2017). Faktor-faktor yang Mempengaruhi Produktivitas Tenaga Kerja Industri Kecil Kota Palopo. Journal of Islamic Education Management, vol 2(2), page 187-198. https://doi.org/DOI: https://doi.org/10.24256/kelola.v2i2.440

Wulandari. (2016). Hubungan Beban Kerja Fisik Manual dan Iklim Kerja terhadap Kelelahan Pekerja Konstruksi bagian Project Renovasi Workshop Mekanik. Kesehatan Masyarakat, Vol 6(2), page 207-215. http://dx.doi.org/10.20473/ijosh.v6i2. 